\title{
First Report of Fusarium pallidoroseum (Cooke) Sacc. on Bael (Aegle marmelos Correa) causing Leaf Spot and Die Back Disease in Nursery
}

\author{
SANTOSH KUMAR, H K SINGH* AND SANJEEV KUMAR
}

\begin{abstract}
Bael is a very popular indigenous fruit of India. Cultivation of bael is a lucrative venture because of its high pharmaceutical importance. The deciduous tree with trifoliate aromatic leaves offering of bael leaves is a compulsory ritual of the worship of lord shiva. In bael nursery, disease appeared during post rainy season (September) as irregular pustules, which was brown in colour, increases very fast and covers the most of the leaf area. After severe infection, affected leaves become dry and fall off. The disease progresses downward causing dieback symptoms but roots remain healthy and they produces new shoots after destroying the vegetative parts. This type of symptoms incited by Fusarium pallidoroseum (Cooke) Sacc. was identified as a causal organism. The pathogenicity test of the fungus was established. Fusarium pallidoroseum produce smooth and creamy white colony, grew rapidly on PDA medium at $25^{\circ} \mathrm{C}$ to $26^{\circ} \mathrm{C}$ and produced rose pink colored woolly to cottony, flat spreading colonies when mature. The mass of the mycelium was very compact in nature. The fungus produced both macro and micro conidia, which are hyaline, septate and ends are also hook shaped. Mycelia are thin and septate. Macro conidia were produced from phialides on unbranched or branched conidiophpres. Macro conidia born in sporodochia were curved; possess a foot cell, 3-5 septate. Micro conidia are single celled, smooth, hyaline, ovoid to cylindrical.
\end{abstract}

KEYWORDS

Aegle marmelos, Fusarium pallidoroseum, leaf spot, dieback

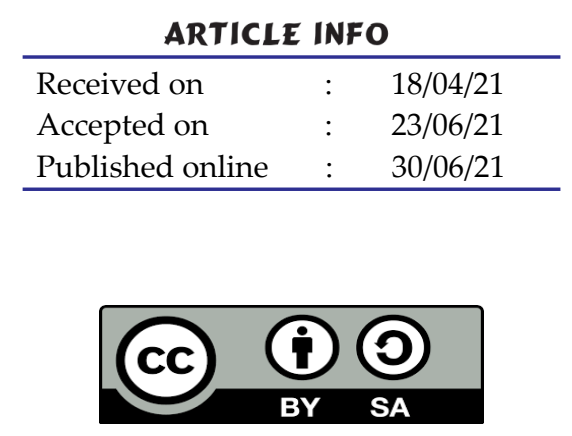

\section{INTRODUCTION}

$\mathrm{B}$ ael (Aegle marmelos L. Correa) is one of the most utilitarian medicinal plants of India; it grows under adverse agro-climatic conditions. It is known by different names in different parts like Bengal quince, golden apple, stone apple, Bael and Sirphal maredu (Andhra Pradesh), bael (Bengal), bil (Gujarat), bil (Himachal Pradesh), bael (Hindi), bilpatra, kumbala, malura (Karnataka), vilwam (Kerala), bilwa (Sanskrit), kuvalum (Tamil Nadu). The deciduous tree with trifoliate aromatic leaves offering of bael leaves is a compulsory ritual of the worship of lord shiva. It has capacity to adapt successfully to a wide range of habitat from arid, semiarid to mesophytic conditions and a wide temperature tolerance (from $-7^{0} \mathrm{C}$ to $48^{\circ} \mathrm{C}$ ). The ripen bael fruits are popular among people because of the delicious fruit pulp, which is ideal for making jam, syrup and pudding. Bael possesses many medicinal values and therefore used as an ingredient in ayurvedic herbal medical preparations. The fruits, bark, leaves, seeds and roots of bael contain bioactive compounds such as coumarin, xanthotoxol, imperatorin, aegelineand marmeline. These compounds can provide anticancerous, antidiabetic, antimicrobial, antifertility, immunogenic and insecticidal activities. Bael is also essential as a species for reforestation, especially in the unfertile marginal lands. Bael seeds possess a unique fatty acid (12 hydroxyoctadeccis 9-enoic acid or ricinoleic acid) a convertible item into biodiesel (Pathirana et al, 2020). The importance of bael lies in its curative properties, make the tree one of the most useful medicinal plant of India. Disease causing agents have potential to imapare the quality of economic produces, and needs time and energy to for its effective management (Singh et al, 2013). Bael nursery plants suffer from a number of fungal foliar diseases namely root rot, collar rot and wilt caused by $\mathrm{F}$. solani, leaf spot caused by Myrothecium roridum and Alternria alternata (Anonymous, 2019).

\section{MATERIALS AND METHODS}

The field experiment was conducted at Main Experiment Station, Horticulture situated at main campus of Narendra Deva University of Agriculture and Technology, Kumarganj, Faizabad (U.P.). This centre is situated between $26.47^{0} \mathrm{~N}$ latitude to $82.12^{\circ} \mathrm{E}$ longitude and at an altitude of $113 \mathrm{~m}$ above mean sea level on Faizabad-Raibarelly road about $42 \mathrm{Km}$ away from Faizabad city. The location falls under Indo-Gangatic plains of Eastern Utter Pradesh of North-India.

\section{Isolation of pathogen}

The diseased leaves were collected from the nursery of bael seedling showing distinct characteristics of symptoms, selected for the isolation of the pathogen. The leaves were washed with fresh sterilized water in order to remove the dust particles and surface contaminants. The washed leaves samples were cut into small bits with some healthy portions with

\footnotetext{
1 Department of Plant Pathology, Acharya Narendra Deva University of Agriculture and Technology, Ayodhya224229 (U.P.), Kumarganj, India

*Corresponding author email: hksndu@gmail.com
} 
the help of flamed razor blade and forceps. The bits were surface sterilized by dipping them in 0.1 per cent mercuric chloride solution for 10-15 seconds under aseptic conditions followed by 3 to 4 washing with sterilized water to remove the traces of mercuric chloride. These bits were de-moisturized by placing them between folds of sterilized filter paper. One such bits were placed separately into sterilized culture tubes containing Potato Dextrose Agar (PDA) under aseptic conditions. These tubes were properly marked with glass marker and incubated at $25+1^{0} \mathrm{C}$.

\section{Pure culture of pathogen}

Pathogens were purified by using single spore isolation technique. Ten $\mathrm{ml}$ of clear, filtered $2 \%$ water agar was poured into sterile Petri-plates and allowed to solidify. Dilute spore suspension was prepared in sterilized distilled water from 20 days old culture. One $\mathrm{ml}$ of such suspension was spread uniformly on agar plate. These plates were incubated at $25 \pm 1^{0} \mathrm{C}$ for $15 \mathrm{hrs}$. and examined under microscope to locate single conidium and marked with permanent marker on the surface of the plates. Single conidium was transferred to Petri-plates having PDA with the help of cork borer under aseptic conditions and incubated at $25 \pm 1^{0} \mathrm{C}$.

\section{Pathogenicity test of Fusarium pallidoroseum}

Seeds of bael were surface sterilized with $0.1 \%$ mercuric chloride and sown in $15 \mathrm{~cm}$ diameter earthen pots containing sterilized soil @ 5 seeds/pot. They were allowed to grow for a month. In each pot 2 plants were maintained. Prior to inoculation, the plants were predisposed to 95 per cent humidity for 24 hours. Thereafter, they were inoculated by conidial suspension having $1 \times 10^{6}$ spores $/ \mathrm{ml}$ with the help of automizer. After inoculation, the plants were kept in the glass house. Control plants were also maintained by spraying sterile distilled water alone. After Symptoms appeared the organism was re-isolated from artificially infected leaves and the culture obtained was compared with the original culture.

\section{RESULTS AND DISCUSSION}

\section{Isolation, Identification and Pathogenicity Test}

After 3 days of incubation on PDA medium, it was found that the fungal mycelium was emerging out from infected leaf portions. This was further sub cultured for the generation of pure culture and was send to Indian Type Culture Collection (ITCC), Division of Plant Pathology, Indian Agricultural Research Institute, New Delhi for identification. The pathogen was identified as Fusarium pallidoroseum with Id No. 9557.14.

The artificially inoculated plants, the disease symptoms were recorded after 7-10 days while dieback symptoms were recorded after 15-20 days of artificial inoculation, which was similar to the original symptoms. The artificially infected plants were used for re-isolation of the pathogen for comparative studies. After pathogenicity test of Fusarium pallidoroseum with disease of bael was associated and confirmed in artificial inoculation trials.

Sympotoms
The disease appeared during post rainy season (September) as irregular pustules which was brown in colour, increases very fast and covers the most of the leaf area. After severe infection, affected leaves become dry and fall off. The disease progresses downward causing dieback symptoms but roots are remain healthy and they produces new shoots after destroying the vegetative parts (Figure 1 \& Figure 2).

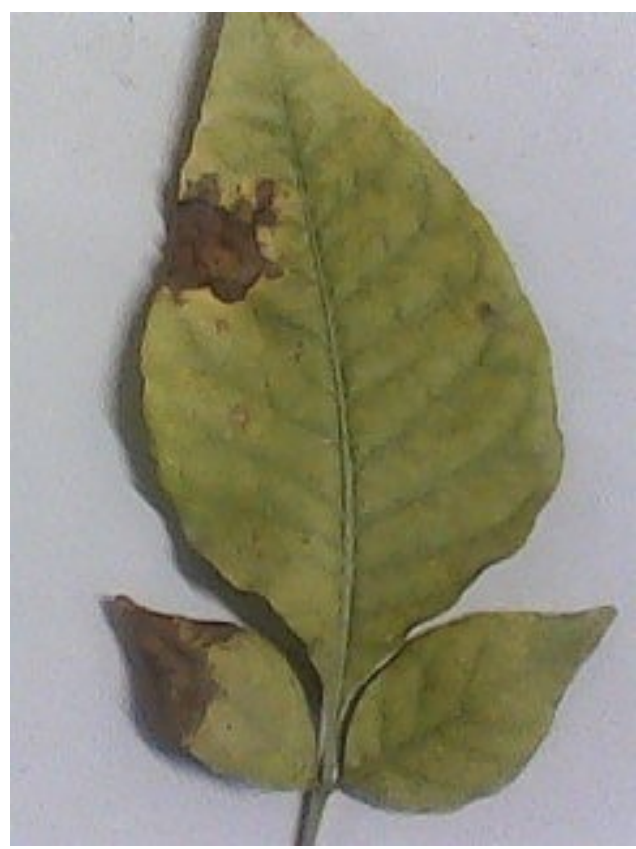

Fig. 1: Leaf spot on bael leaf

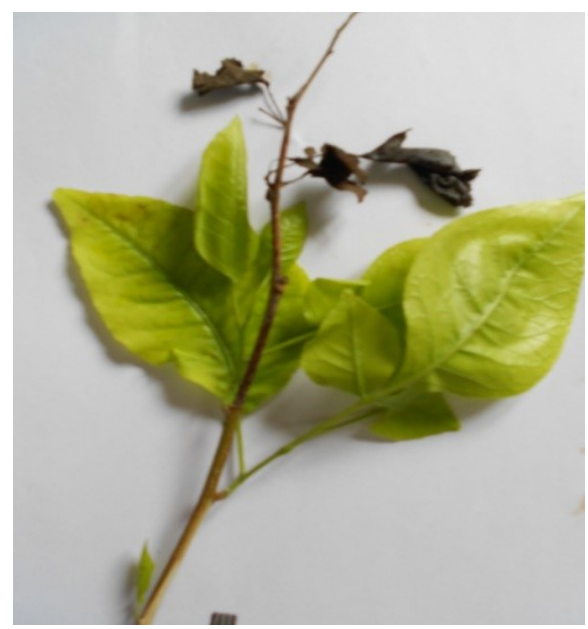

Fig. 2: Dieback symptoms on stem

Much vegetative loss have been recorded in the nursery with this disease. Die-back of branches caused by Fusarium pallidoroseum were recorded in bamboo plantations as well as natural stands (Mohanan, 1994). Bose et al (2010) was also recorded different types of symptoms on Chlorophytum nepalense incited by Fusarium pallidoroseum. (Gupta et al, 1997). 

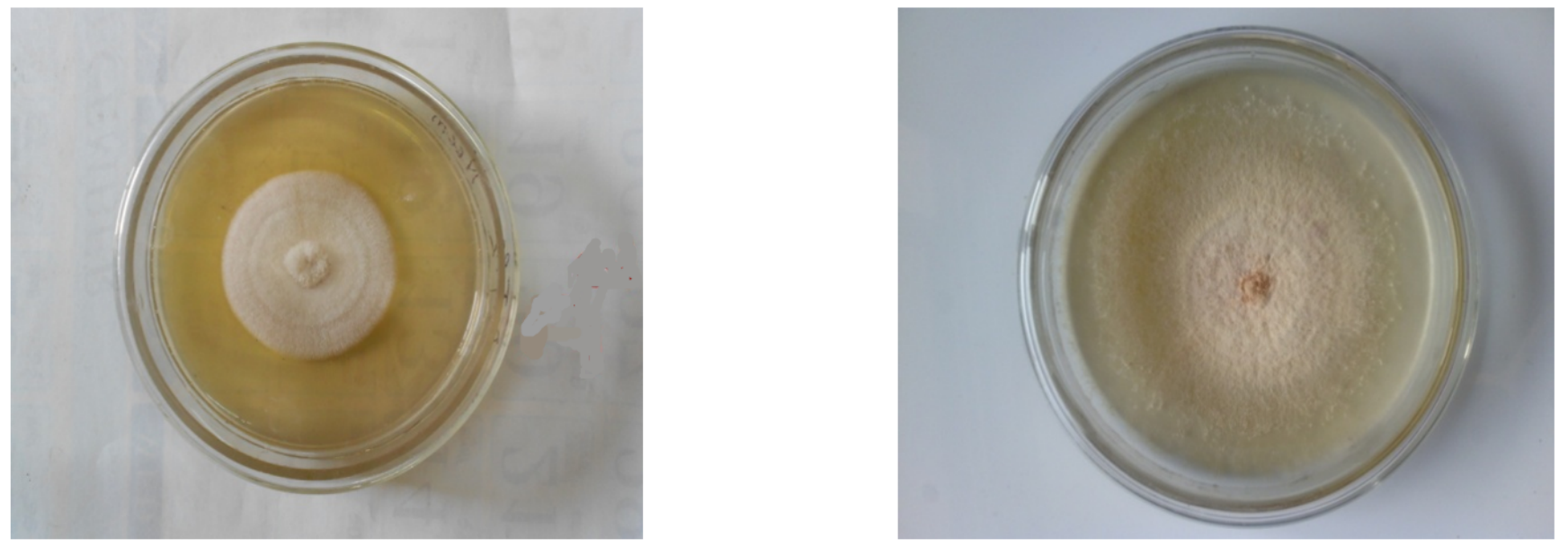

Fig. 3: Cultural pattern of Fusarium pallidoroseum on PDA after15 days of inoculation
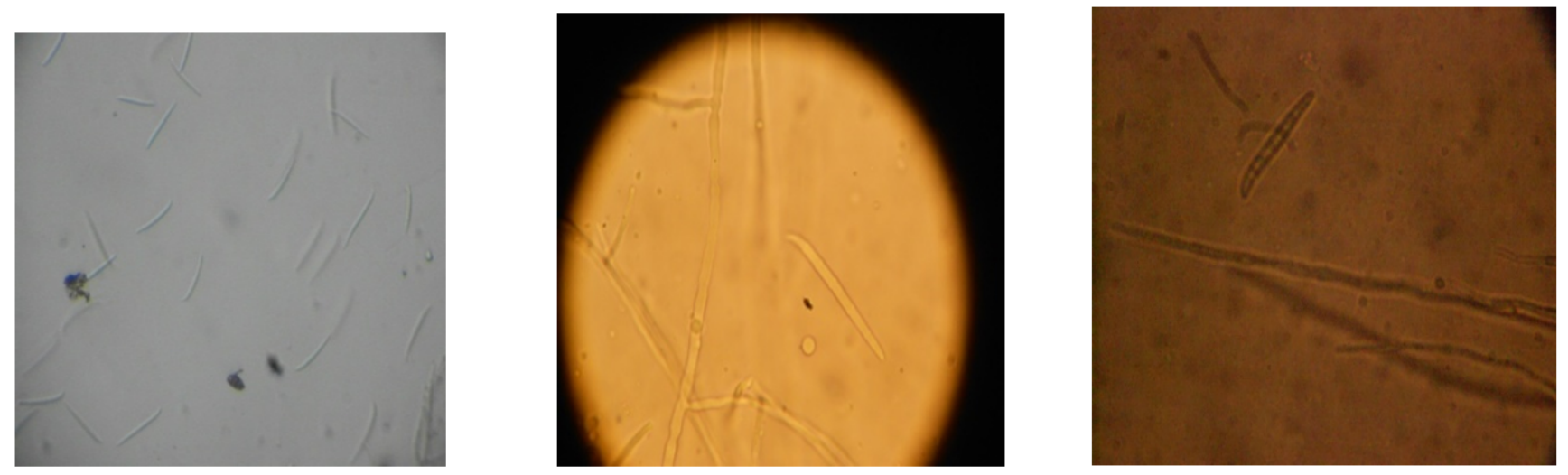

Fig. 4: Conidia and conidiophores of Fusarium pallidoroseum

observed the occurrence of various diseases viz., stem-canker, cutting rot, collar rot, sprout/leaf blight, die-back and root rot were observed in mulberry nurseries which was caused by Botryodiplodia theobromae, Fusarium solani, Phoma sorghina, F. pallidoroseum and Colletotrichum gloeosporioides.

\section{Microscopic features}

Fusarium pallidoroseum produce smooth and creamy white colony, grew rapidly on PDA medium at $25{ }^{\circ} \mathrm{C}$ to $26{ }^{\circ} \mathrm{C}$ and produced rose pink colored woolly to cottony, flat spreading colonies when mature. The mass of the mycelium was very compact in nature. From the reserve it gave an oranges tan colored appearance around the colony region in PDA medium (Figure 3). The fungus produced both macro and micro conidia which are hyaline, septate and end are also hook shaped. Mycelia are thin and septate. Macro conidia were produced from phialides on unbranched or branched conidiophpres. Macro conidia born in sporodochia were curved, possess a foot cell, 3-5 septate. Micro conidia are single celled, smooth, hyaline, ovoid to cylindrical (Figure 4). Bose et al (2010) and Bose et al (2010) observed that macro conidia born in sporodochia are curved, possess a hya- line foot cell, 3-7 septate and micro conidia born on short simple conidiophores were observed in old cultures. Diversity in colony colour, growth, its margin and topography were noticed on Chlorophytum nepalense caused by Fusarium pallidoroseum (Pathirana et al, 2020).

\section{CONCLUSION}

The present studies, there is no reports of earlier from India in disease of bael nursery caused by Fusarium pallidoroseum (Cooke) Sacc. The disease appeared during post rainy season (September) as irregular pustules, which was brown in colour, increases very fast and covers the most of the leaf area. After severe infection, affected leaves become dry and fall off. The disease progresses downward causing dieback symptoms but roots are remain healthy and they produces new shoots after destroying the vegetative parts. The fungus Fusarium pallidoroseum causing leaf spot and dieback on bael have been reported first time from India. The review of literature showed that it is a new record on bael from India. 


\section{ACKNOWLEDGEMENTS}

Authors are thankful to Director, Central Institute of Arid Horticulture, Bikaner and Indian Type Culture Collection

\section{REFERENCES}

Anonymous. 2019. The cause of wilting/drying in bael plants. Annual Progress Report of AICRP on Arid Zone Fruits (ICAR) 196-196.

Bose T, Ghosh GS and N. 2010. First report of Fusarium pallidoroseum (Cooke) Sacc. causing wilt disease of Chlorophytum nepalense (Lindley) Baker. J. Mycopathol. Res 48(1):111-114.

Gupta VP, Govindaiah and Raju HV. 1997. Diseases and associated fungal pathogens of mulberry nurseries. Indian Phytopath 50(3):402-407.
(ITCC), Division of Plant Pathology IARI New Delhi for identification of the pathogen with Id No. 9557.14.

Mohanan C. 1994. Diseases of bamboos and rattans in Kerala. Kerala Forest Research Institute Peechi. Thrissur Kfri Research Report 98.

Pathirana CK, Eeswara MT and J 2020. url: https://doi.org/10.1155/ 2020/8814018.

Singh AK, Bhatt BP and Manibhushan. 2013. Occurrence of Phytoplasma phyllody and witches' broom disease of faba bean in Bihar. J. Environ. Biol 34:837-840. 